Canadian University Music Review

Canadian University Music Review

Revue de musique des universités canadiennes

\title{
The Well-Furnished Film: Satie's Score for Entr'acte
}

\section{Martin Marks}

Numéro 4, 1983

URI : https://id.erudit.org/iderudit/1013906ar

DOI : https://doi.org/10.7202/1013906ar

Aller au sommaire du numéro

\section{Éditeur(s)}

Canadian University Music Society / Société de musique des universités

canadiennes

\section{ISSN}

0710-0353 (imprimé)

2291-2436 (numérique)

Découvrir la revue

\section{Citer cet article}

Marks, M. (1983). The Well-Furnished Film: Satie's Score for Entr'acte. Canadian University Music Review / Revue de musique des universités canadiennes, (4), 245-277. https://doi.org/10.7202/1013906ar

(c) Canadian University Music Society / Société de musique des universités canadiennes, 1983
Ce document est protégé par la loi sur le droit d'auteur. L'utilisation des services d'Érudit (y compris la reproduction) est assujettie à sa politique d'utilisation que vous pouvez consulter en ligne.

https://apropos.erudit.org/fr/usagers/politique-dutilisation/ 


\title{
THE WELL-FURNISHED FILM: SATIE'S SCORE FOR ENTR'ACTE
}

\author{
Martin Marks
}

Throughout their history, motion pictures have been accompanied by music, and the combination has affected us in a variety of ways both simple and subtle. Like the film medium itself, moreover, film music has undergone such rapid development that today it ranks among the most widely dispersed and influential genres of dramatic music. For all its influence and importance, however, film music has fared rather poorly as a subject of scholarly inquiry. In part this neglect is due to film music's unusual position: it inhabits a special domain, removed from the older and more traditional forms of music-making. Its world is that of the motion picture theater, rather than the concert hall or the written score. Thus the study of the history and theory of film music depends upon the study of film itself; and careful analysis of a motion picture score requires that the music be examined side by side with the film for which it was composed.

Such analyses are very much needed for the advancement of our understanding of fílm music, and a fascinating example with which to begin is Erik Satie's score for Entr'acte. This is the first complete original score we have by a leading avantgarde composer; and although it is Satie's only film score, composed for a picture lasting a scant twenty minutes, it has been highly praised and even termed a model of film music (see Gallez 1976). But if it is a model, it is a thoroughly puzzling one, rich in paradoxical effects and novel solutions to the problems of film music. The film's unconventional nature forced Satie (or rather, reinforced his customary desire) to compose unconventional music. His score called into question the prevailing film music aesthetic of its time, on behalf of an avant-garde 
seeking new forms and meanings in the artful combination of music and image.

As its title indicates, Entr'acte was an "intermission piece." Directed by René Clair, the film was originally presented between the two acts of the ballet Relâche, as premiered at the Champs-Elysées Theater in Paris on 4 December 1924. Satie composed the ballet's music, Francis Picabia created its scenario and design, Jean Börlin its choreography.

These men were all conspicuous figures in the world of Parisian avant-garde art. Satie was widely known for his unconventional theater pieces (beginning with Parade in 1917), as well as for his humorous bits of prose and his role as mentor to "progressive" young composers like the "Six." Picabia was frenetically active as a painter, poet, publisher, and prince of Dada. And Börlin danced for the Ballets Suédois-a company which (under the stewardship of Rolf de Maré) had become notorious for its premieres full of provocation and scandal. 1 Relâche, it was hoped, would be no exception. Satie had sent word to Picabia that the ballet might spark "a true revolution . . . a new DADA." 2 To his young friend Milhaud he wrote playfully of the impending "tornado." ${ }^{3}$ Audience excitement was heightened by means of a lengthy and tantalizing publicity campaign promising an evening of anarchic spectacle. ${ }^{4}$ Moreover, the premiere itself was delayed for a week (from November 27)-but only after the gala audience had been allowed to mill in front of the Champs-Elysées Theater with mounting confusion. Since Relâche means (in theatrical parlance) "no show tonight," many people began to suspect the ultimate Dada joke: a ballet that was to be no ballet at all. ${ }^{5}$

The joke turned out differently: when the premiere did take place, Relâche failed to arouse its audience; and whether deservedly or not, the ballet has been overshadowed by its Entr'acte from that first night until the present day. Relâche was the last work to be mounted by De Maré's company; the ballet closed after about a dozen performances, and it has rarely been revived since. ${ }^{6}$ But the Entracte has never been allowed to slip from view. It is continually re-screened; its script has been published; ${ }^{7}$ and as Clair's fame has grown, the film has been analyzed with some frequency. ${ }^{8}$ Among film intelligentsia, critical opinion is 
clear: Entr'acte remains one of the most delightful products of experimental film-making to emerge from post-war France.

Yet it is easier to appreciate Entr'acte, and to enjoy its humor and vitality, than to explain what the film is about. Though short, it is crammed with hundreds of motion-filled shots that bewilder us with their speed, fantasy, and dazzling technique, Non sequiturs abound: one moment we behold a paper boat sailing over the roofs of Paris; next, the legs of a ballerina leap in a darkened studio. There are illogical jokes in abundance, too: for example, when the camera pans up the ballerina's body, "she" is revealed to be a bearded man; when it pans down from the tips of her upstretched hands, the dancer's true face comes into view. Later in the film, while assembling for a funeral procession, one mourner breaks a piece of bread from a loaf hanging on the back of the hearse. He eats it, incurring the disapproval of his companion. The hearse, we discover, is drawn by a camel; the mourners, leaping in slow motion, follow its trail into an amusement park.

With such incidents as these in view, Entr'acte appears to be a Dadaist farce, and Picabia exalted it as such. He called the film "a true entr'acte, an intermission from the imbecilities of everyday life, and a break from all ridiculous and hypocritical conventions" (1924a: 3). ${ }^{9}$ If the film shows disrespect for art (as personified by the ballerina) and for the dead, the reason, as Picabia put it, is that "Entr'acte respects nothing, except the wish to burst out laughing" (ibid.). But in fact the film takes off its hat to more than humor. Entr'acte was René Clair's second picture, the work of a young man in love with the camera and what it could do. He treated it like a new-found toy, and organized its playful images with a remarkable array of effects: complex rapid-fire editing, dense superimpositions, rhythmic manipulations from slow to fast motion and back-all in the interest of developing a new language for cinema. For during the years following World War I, among the intermingled circles of Clair, Picabia, and Satie, there had developed a "New Spirit" of appreciation for the unique properties of the film medium. ${ }^{10}$ Those artists who wrote about film (like Clair himself) placed great emphasis on the need to develop "pure" cinema-that is, cinema based on inherently visual styles, divorced from literature and theater, and shaped into anti-narrative (often dreamlike) forms. "Thus came Entr'acte," wrote Clair, "claiming to give the [cinematic] image new value" (1924: 3). ${ }^{11}$ 
Thus, too, came Satie's score, which many claim gave new values and functions to film music. During the mature phase of the silent period (from about 1915 on), most films were products of an industry geared to supplying audiences with entertaining stories; and music was normally expected (as it still is today) to underline and interpret the narratives, with careful reflections of a film's settings, characters, actions, and moods. But as we have seen, Clair's film came out of an altogether different world; the "story" it tells is at best a puzzle; and at first hearing, Satie's music seems to exist in a puzzling world of its own. That is, rather than string together a series of mood or action pieces (as was the convention), or a series of leitmotifs in a pseudoWagnerian manner, Satie built his score entirely out of repetitive patterns strung together in four- and eight-measure units (see the opening measures in Ex. 1). ${ }^{12}$ The music is buoyant, full of momentum, and harmonically ambiguous. Its crazy-quilt style may, in some general fashion, reflect the anarchic torrent of images. But does the music interpret Entr'acte in any more specific way than this?

For the most part, Satie's commentators have answered the question in the negative; and in the composer's departure from the norms of film music-in his apparent refusal to interpret the screen images - they have affirmed his understanding of the true nature of film music. That is, it has been repeatedly written that the Entr'acte score is "good" film music precisely because it is so unpretentious, so unwilling to call attention to itself by commenting on the images. Thus the music's "identity" has been said to be subordinated to the film's; moreover, this unobstrusive quality (as it is perceived) makes the score the supreme example of what Satie called "musique d'ameublement," or "furniture music." 13

This was a term Satie employed throughout his final years, usually in a semi-parodistic manner. He meant to delineate a realm of functional music belonging uniquely to the twentieth century: music "furnished" on specification like an industrial product, or music "built" like furniture-designed, that is, to provide comfort and support for some other activity:

What we want is to establish a music made to satisfy "useful" needs. Art does not enter into this. "Furniture Music" creates a vibration: it has no other goal; it fills the same role as light and heat-as comfort in all its forms (quoted in Shattuck 1968: 169). ${ }^{14}$ 
As others have subsequently realized, the "needs" in question usually seem to arise in public environments requiring unobtrusive musical backgrounds: supermarkets and elevators, for example, filled with soothing Muzak, or motion picture theaters, filled with "furniture music," or "background music," or "wallpaper music." All of these synonymous terms have been used to express the idea that film music does function in a fundamental way like furniture. Hence, in the earliest days of the silent film, many theaters were filled with sounds from furniture-like mechanical pianos, installed by economy-minded theater owners to provide a continuous musical background. This music may have had little relevance to the screen image; but still it supplied audiences with a much-appreciated "cushion," enabling them to sit more comfortably than they would in a "silent" theater, where either noises would distract them from the imagined world on screen, or silence would oppress.

The point is, however, that all film music-whether mechanical, live, or recorded on soundtrack or tape-fulfills these important psychological needs: invariably the patterns of sound unite us (though we be scattered in a darkened theater) as an audience; they also isolate us from the external world and thereby bring us closer to the world on screen; and if the music is well made, it helps in countless ways to bring that world to life. These are all basic functions of film music, but they take us far beyond the properties of furniture. For even the most "unobtrusive" accompaniment (however that intangible quality is to be measured) plays a much more active role than ambient "light and heat."

To regard the Entracte score as one which limits itself to being like furniture music is both instructive and misleading: instructive, because undoubtedly there is something peculiarly circumspect about this music; misleading, because the perspective afforded by the concept of furniture music leaves much of the score's depth out of the picture. It should be remembered, moreover, that Satie himself is not known ever to have related musique d'ameublement explicitly to Entr'acte, or even to film music in general. ${ }^{15}$ At best we can assert that the composer implicitly saw a connection and determined to make a furniture music style-detached, repetitive, unassertive-the starting point of his score. (Such a style could be termed the starting point of many of his scores.) But the music of Entr'acte as a whole enjoys a dynamic relationship with a complex film. The 
score helps to elucidate the film's structure and to extend its range of meanings, in a manner that deservedly brings the music to the foreground of our attention.

The close affinities between Satie's music and Clair's film are apparent from the outset, when the opening measures of the score are examined with the images they accompany in view. We find at the beginning a series of oscillating patterns. The music, in Satie's phrase for furniture music, "creates a vibration" -or rather, one pattern of vibration after another. Overall, the prevalent characteristics of these patterns are buoyancy, suggested by the bouncing and dissonant figures which blithely refuse to resolve, momentum, sustained by the constant tempo, the lack of cadences, and the grouping of units into four and eight measures, and discontinuity, caused by the abrupt shifts which isolate each unit in terms of "theme," key area (which is often ambiguous), and texture. The discontinuity is made even more pronounced by changes of orchestration, since no two units are scored alike. Satie borrowed his orchestra from the pit of the music hall; but rarely does the score call for the whole orchestra at once. ${ }^{16}$ Instead, various soloists and small combinations do "turns"-and the turns are frequently comic. The fourth unit (mm. 21-28 of Ex. 1), for example, gives us a little bit of "traveling music," but paradoxically the music goes nowhere. The oboe's and horn's oscillating two-note "melody" sits above the strings' oom-pah bass, while the wood block jauntily canters in dotted rhythm. In this unit, as in many others, there is a light-hearted sense of parody of music drawn from the popular arena; otherwise, the whole seems governed by a peculiarly neutral quality: a tone of ironic detachment and motion without a goal. 

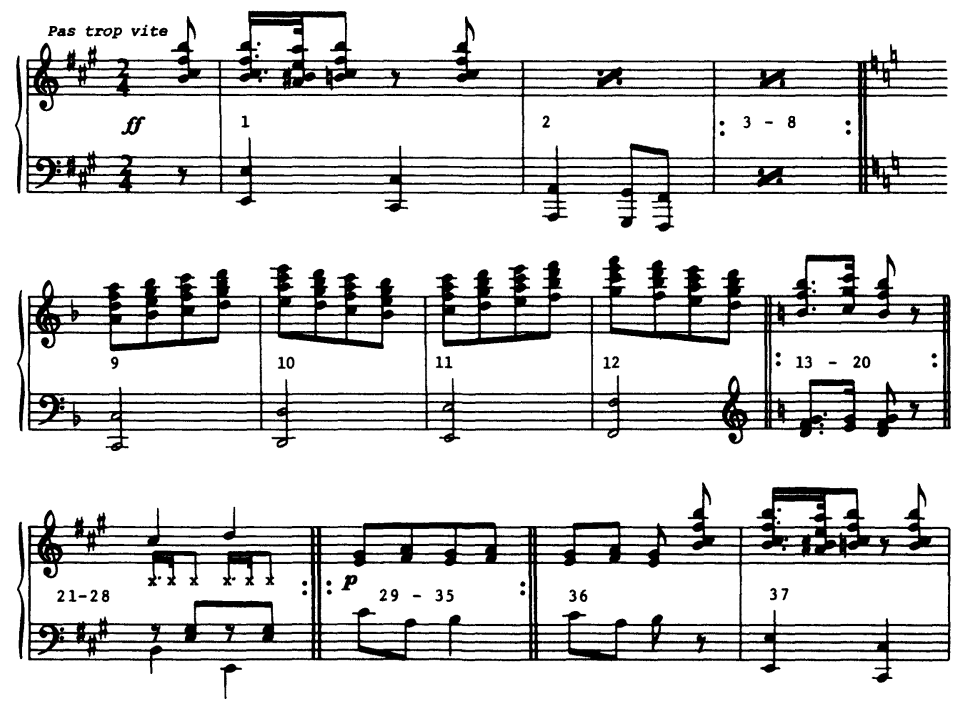

Satie: Entr'acte (1924), opening measures.*

Example 1

What this peculiar music accompanies on the screen is no less bizarre. Entr'acte begins with a jerky and bewildering series of disconnected images. ${ }^{17}$ It pictures a world in constant flux, even (as in shots 2-12) a world turned upside down. Indeed, the whole beginning makes a playful attack on its audience and on their sense of what film can do. Nothing is fixed. We see the painted heads of three little dolls in some kind of carriage-the caricature of a complacent family threesome out for a ride; but their trip takes a different turn when the heads deflate, re-inflate, and deflate again-probably a symbol of the puffed-up pretensions of the bourgeoisie. Thus, each image seeks to provoke the audience in some comic fashion; but most provocative of all is the utter discontinuity itself: 
The Opening Shots of Entr'acte ${ }^{18}$

1. Fade in to shot of coruscating dots of light with halos. The halos fade and the dots recede.

2-11. Fade in on a series of eleven different long shots of houses and roofs seen diagonally or completely upside down. They are all very short and each shot dissolves rapidly into the next. (Shots 3-5 are superimposed on other, fainter shots of similar roofs.)

12. Medium close-up of three little dolls-one male, two female, against a background of painted flowers. Their heads are balloons with faces painted on them. Through an aperture behind them, which looks like the back window of a car, roofs and houses can be seen passing rapidly from left to right. 13. Long shot of houses and chimneys upside down.

14. Resume on the three dolls.

15. Close-up of one of the female dolls whose head slowly deflates and flops onto its shoulder.

16. Resume on medium close-up of the dolls, all their heads deflated.

17. Close-up of the male doll whose head reinflates and swells to its original size.

18. Medium close-up of a ballerina in a tutu shot directly from below, twirling round on a sheet of glass.

19. Resume on the three dolls, all their heads re-inflated.

20. Extremely fast tracking shot, looking directly upwards from beneath some trees, with rays of sunlight sparkling through the branches.

21. Resume on the three dolls again with their heads deflated. Fade out.

22. Fade in to another shot of dots of light; they expand and contract as they move in and out of focus. Amorphous moving shapes fade in behind them.

23. Close-up of white boxing gloves on a black background. They throw rapid punches at each other, moving out of shot and back again. At the end of the shot the arms of the boxers are clearly visible. Fade in to a high angle long shot of the Place de l'Opéra in the daytime; the boxing gloves are superimposed still punching at each other. Camera tracks out slightly.

The beginning of Entr'acte comes close to realizing one of Picabia's happiest phrases for the cinema: "an evocative invention, as rapid as the thought of our brain." ${ }^{19}$ Responding to these imagistic flashes of thought, the music attempts to keep up. It does not do so, however, by changing for each new shot. Such a method 
would be all but impossible, given the speed with which the images fly by. Instead, the music imitates the film's content by means of the characteristics emphasized above. The buoyancy of the first theme, for example, seems perfectly suited to the image of bouncing dots of light it accompanies at the start. (We shall return to the larger-scale functions of this particular theme below.) The film's constant fast-paced movement is mirrored by the music's quick tempo and unflagging momentum. Above all, the shifting fragments, discontinuities, and (as the film keeps going) dream-like recurrences are common to both film and music.

They also share a common tone, at once detached and humorous. It might be said that both chords and pictures have been abstracted from normal positions and meanings for the purpose of comic disorientation. We can hear, for example, the harmonic basis of each musical unit: A major in the first, $F$ in the second, $C$ in the third; but no cadences ever confirm these keys or resolve the "wrong" notes. Indeed, so many notes sound out of place, and so many key areas are abruptly juxtaposed that the chords tend to lose their functional significance. Likewise the pictures have no solid context. Some of them have even detached themselves from what they really represent. The dots of light, for example, are in fact the street lights of Paris (as we later discover), altered and made to move by changing the position of the camera lens. ${ }^{20}$

If Satie placed chords in functional contexts only to undermine them, he did so because Clair tried as much as possible to "liberate" the film's imagés (see Clair 1924). ${ }^{21}$ At the beginning the effect is one of exhilarating anarchy; elsewhere the results of the camera-play become strangely beautiful. The ballerina, for example, becomes a symbol of art seen in a new perspectiveone, it should be noted, obtainable only with the techniques of film photography. Viewed from a seemingly pornographic angle (in shot 18, and at much greater length later in the film), her exercises become a fascinating rhythmic study; and owing to the shot's use of light and shade, her tutu seems to open and close like the petals of a white flower. ${ }^{22}$

The ballerina sequence is altogether different in effect from the barrage of images at the film's beginning. For after introducing us to a film in which conventional narrative seemingly has no place, Clair shifts his strategy and offers teasing glimpses of narrative fragments: first a chess game between Marcel Duchamp 
and Man Ray, next the ballerina in practice, and then a hunter (Börlin of the Ballets Suédois) attempting (as if he were in a fairground booth) to shoot an egg balancing on a jet of water. Each of these fragments is somewhat longer than the preceding, and as the film images begin to join together into larger sequences, the musical units group themselves accordingly. The score, like the film, never completely loses its momentum-the four- and eight-measure units remain constant, as do the harmonic ambiguities which push the music forward-but within the framework of this style the music alters considerably in relationship to the film.

One key to our perception of these relationships is to be found in the series of cues printed in the published scores, probably according to notes made by Satie as he was at work on Entr'acte. ${ }^{23}$ There are ten of these cues, or score headings (to which I have added roman numerals), as follows:

I. Chimneys; deflating balloons

II. Boxing gloves and matches

III. Scenes from the air; chess game and boats on roof

IV. The female dancer and figures within water

V. The hunter and the beginning of the funeral

VI. Funeral March

VII. Funeral procession in slow motion

VIII. The chase

IX. The coffin's fall and the emergence of Börlin

$X$. The End (Screen bursts and The End)

While the score leaves much unsaid concerning matters of tempo and repetition of units (perhaps because Satie did not live to see it through publication), these cues do provide performers with basic indications of how to fit the music to the film. They reveal to us, moreover, that Satie comprehended the film in ten large sections and that he took pains to reflect the film's organization in his score, developing connections between particular units and images, as well as between music and images of sections overall.

One way in which Satie articulates the sectional structure is through his use of cadences. We have already observed the lack of cadences at the beginning of the score-Satie's purpose being to sustain a constant sense of motion. But he had another purpose as well: to join the first two sections into a still larger grouping of twelve musical units. ${ }^{24}$ Several of the oscillating 
patterns in the first section are repeated in the second, although in a different order (an intriguing procedure which Satie also followed in linking the two acts of Relâche). Among the units that recur, the first is most prominent. It is heard three times, in such a way as to delineate the sectional structure: first at the beginning of the score, next at the beginning of Section II (Ex. 1, $m$. 37), then at the end of Section II, but with a tremendous difference. After six bars the downbeat chord "freezes" like a photographic frame; the music "cadences," simply by coming to a stop (Ex. 2):

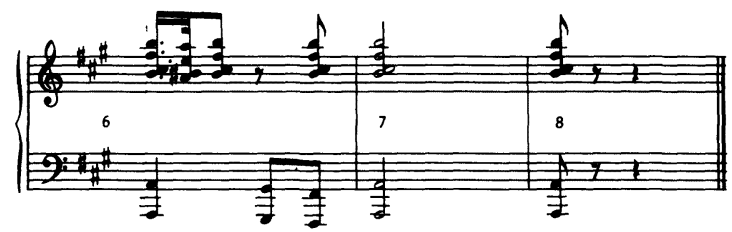

Satie: Entr'acte, the end of Section III.

(mm. 1-5 of this unit are identical to mm. 1-5 of Ex. 1)

Example 2

The sudden halt serves two purposes. First, it gives punch to the joke that ends the second section: superimposed images of matches spin and blaze in a man's hair; he scratches his head, then looks at the camera in surprise, and it is as if the music stops short in surprise along with him. But the sudden pause also gives emphasis to the stylistic continuity of the first two sections, and to the predominance of the opening music-a unit stressed so much that it might well be termed the "theme" of Entr'acte. There is, moreover, a thematic unity to all the images this music accompanies: bouncing discs of light, bouncing white boxing gloves, matches moving in a man's hair. On an abstract level, all these images are of a type: inanimate objects made animate, defying gravity and the natural order, moving in air or hair. These are the ideas that set Entr'acte in motion; and the opening musical figure reflects them. It defies musical "gravity" by refusing to come to rest on the solid ground of an A major chord. Its melody keeps bobbing back up to the pitch just above the tonic. More generally, its buoyancy sets the pace and character for all the music of the first two sections. Only when the film is about to change does Satie bring this unit to a halt.

The change comes with Section III, where the film begins to 
depart from its purely abstract character to tell its first little story. ${ }^{25}$ Pillars are shown at various angles, then superimposed in a criss-cross pattern that leads metaphorically to the shot of a chess board. A camera tracks across the pillars, first to the left, then to the right. The two players, Duchamp and Man Ray, are shown together, then one after another. We sense in all this that the film's tensions have begun to stabilize, to find rest and balance-and Satie's music pretends to do the same. The first unit of this section oscillates like all the earlier ones; but the pattern has been fit into two sub-phrases, an antecedent and a consequent of three-plus-one bars each (Ex. 3):

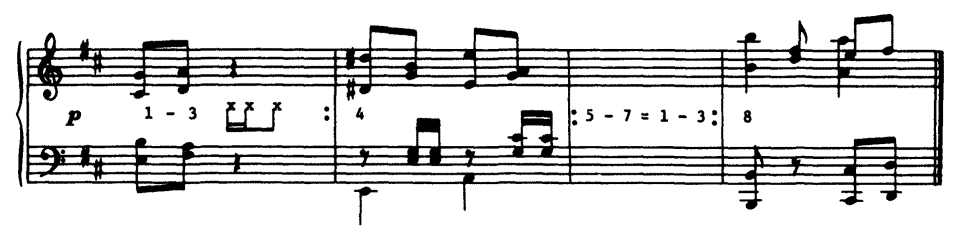

Satie: Entr'acte, the first unit of Section III.

Example 3

This new phraseology is quickly parodied by the third unit of the section: a twelve-bar (!) unit, subdivided into phrases of seven and five bars each (Ex. 4):

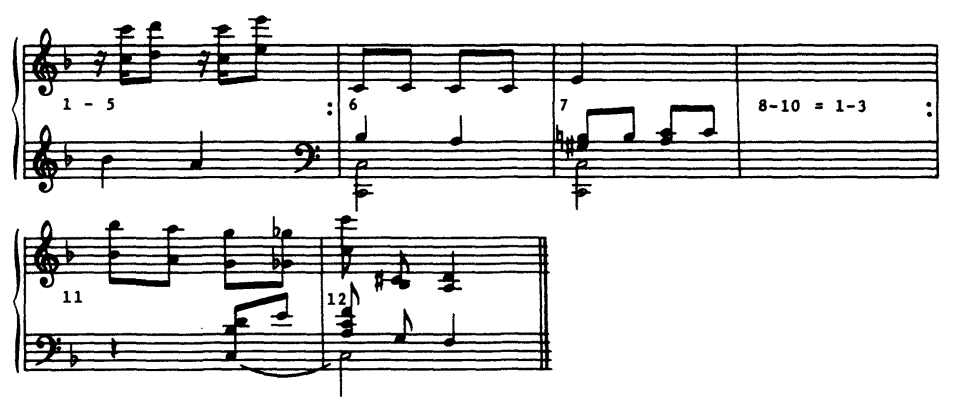

Satie: Entr'acte, the third unit of Section III.

Example 4

With their perky cadences, these units are at once balanced and comically out of kilter-a playful ambiguity driven home by the last part of this section. The game, it turns out, is on no more 
solid ground than the rest of the film. Indeed, it is being played on a parapet, vulnerable to attack, and suddenly a stream of water blows the players and the game away. While a paper boat floats dreamily across the roofs of Paris, the music floats with it; but in this last unit of Section III there is another unbalanced outburst: four loud chords sound an ironically emphatic cadence (Ex. 5):

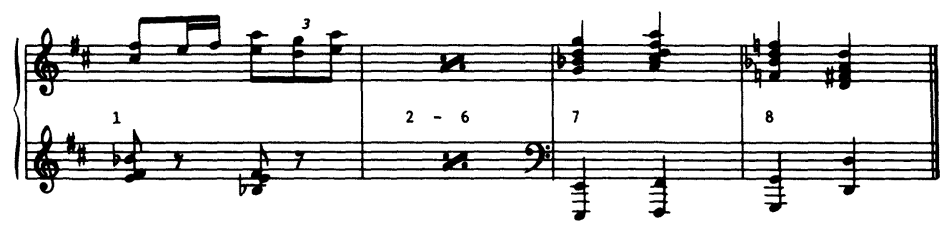

Satie: Entracte, the last unit of Section III.

Example 5

Once again, a cadence both emphasizes a joke and divides two sections. This time the close is far stronger (though no less abrupt) than the one which ended Section II. But what makes it especially ironic is that it articulates a division between images which the film interconnects. Clair cuts back and forth between shots of the paper boat and the ballerina who holds center stage in Section IV. ${ }^{26}$ His point is to stress the metaphorical resemblance of their movement (as he did the pictorial resemblance between crossed pillars and chess board), and thereby to establish continuities beneath the film's choppy surface. We thus perceive the boat as a transitional image: its voyage is launched by the stream of water that breaks up the game; its goal is the ballerina's studio.

It is extremely difficult to duplicate such a dreamlike visual continuity in music-particularly music so discontinuous in style as the Entr'acte score. When Satie introduces cadences, he awakens us to shifts in the film, ignoring the hidden logic that holds the images together. The cadence at the end of Section III calls attention to itself with the force of an alarm clock; and yet-having granted this-we ought also to recognize that the "boat music" does subtly prepare for the music to come. Its triplets (the first in the score) anticipate the triple meter of Section IV. ${ }^{27}$ Its angular oscillating line (which perhaps mirrors the boat's angular movement) hints at the arch-like melody that follows. (Compare Ex. 5 \& 6): 


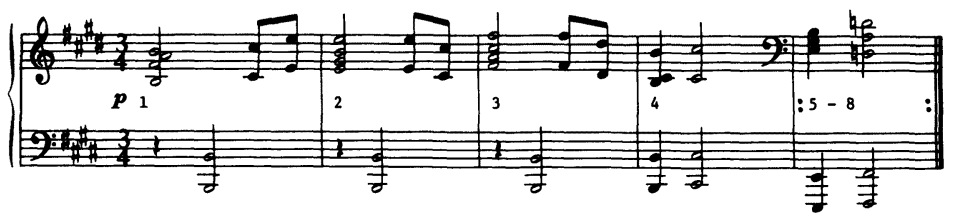

Satie: Entr'acte, the first unit of Section IV.

Example 6

These are subtle anticipations, however, apt to impress us only subliminally (or perhaps only after analysis). What we are much more likely to respond to are the great differences between Section IV and all that has preceded. The novel beauty of the ballerina's exercises have already been described; there is an equally novel beauty to her music. The meter changes, the tempo slows, and the new melody is in effect the first real tune of the score. Even though it lasts only four bars, it sets a gentle mood that suffuses the whole section. The line's lyrical arch well suits the graceful motions of the dancer. All the succeeding patterns are light and smooth; all are eight measures long, neatly divided in half. Neither harmony nor orchestration jars. Satie also rounds off this section smoothly, with a return of its opening melody.

As we might by now expect, a cadence brings Section IV to a close (Ex. 7):

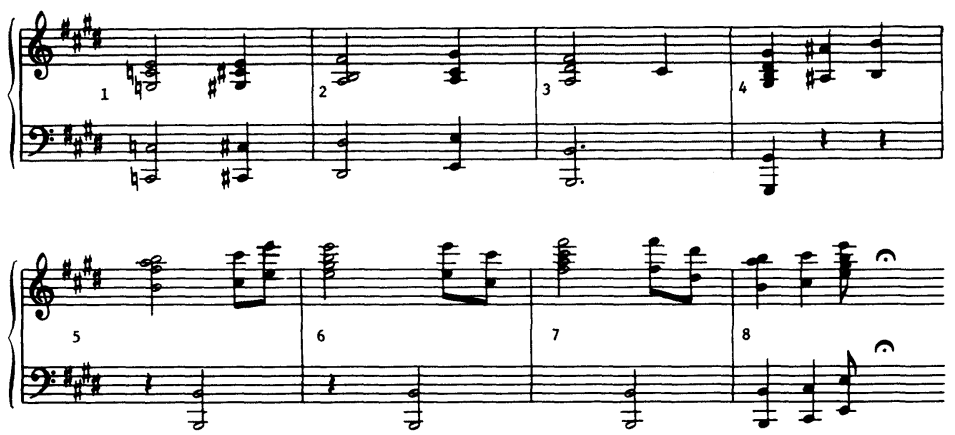

Satie: Entracte, the last unit of Section IV.

Example 7

It is even more emphatic than the one that ended Section III, and even more ironic in its effect. As the waltz theme returns, we behold a puzzling set of superimposed images so intricate 
that our sense of a "reality" behind them all but collapses. ${ }^{28}$ Various pairs of eyes, a ballerina's tutu, a face upside down that merges into a mirror image of itself-these and other pictures melt into one another and into a rippling layer of water "behind" them. Yet the music becomes massively warm, familiar and grand, as if attempting with its cadence to supply a foundation missing in the film.

But stability is not to be had. Suddenly the opening music returns once more, and we behold an egg balancing on a jet of water, then Börlin, the hunter, preparing to shoot it. The water frustrates his intent, however, by being as unstable an element here as it has been all along. The jet bobs up and down, as does the egg. Indeed, the egg even refuses to remain itself. While the hunter stands vexed, the egg bounces and multiplies, remultiplies, and demultiplies. When finally the water stabilizes, the egg stops moving and the hunter pulls the trigger-only to have this sequence explode (like all the others) with jokes. The egg hatches a dove that comes to rest on the brim of Börlin's hat. While the hunter and target cheerfully converse, Börlin is himself stalked and shot by his "creator," Picabia. He plummets from a roof and out of the picture.

The opening music dominates this section even more than it did the first two, but in an altogether new way. While the hunter watches the egg in exasperation, Satie instructs performers to repeat this same musical unit until he is shot-usually meaning at least sixty measures of a pattern by now very familiar. ${ }^{29}$ Did Satie adopt this device because he discovered his score was too short for the film? Perhaps-and yet even this music closely parallels the film in its effect. With its high level of dissonance and rhythmic agitation, the music helps to keep this story up in the air, on edge, until the hunter is brought down. (The double shooting is thus tied together with a single musical thread; and the music does not give away the joke on Börlin.) The more it is prolonged, the more it can generate tension-first as mirror to the hunter's own, and next, while he is being stalked, as an expression of the audience's suspense.

But the ultimate effect is somewhat more complex. It would be hard to imagine film music more obtrusive than this (although some of its vexing quality might well be softened in performance). ${ }^{30}$ Confronted by the exasperating repetitions, we may find ourselves "tuning out" from the music and the film, forced into a position of ironic detachment. Such a distancing effect 
may have been precisely Satie's intention-to keep us from taking anything in the world of Entr'acte too seriously. The music thereby encloses us in paradox: it seems to be calling attention to itself-and mocking the film-at a point where it could claim to be following the story quite closely. Satie being Satie, he must have enjoyed this paradox, even if we do not; and Entr'acte being Entr'acte, the paradox is not resolved. When Börlin falls, the music stops. Then both music and image move in new directions.

Before we move with the film, the sudden pause affords us a moment to consider larger questions concerning the overall structure of the score. As was remarked above, the opening theme serves as a point of departure, a central pillar, and a point of return for the first two sections. Halfway through the film it becomes apparent that something like the same design governs the score as a whole, since the opening music dominates the beginning, middle, and end sections. The whole mirrors the part (according to a structural procedure that Satie also made use of in composing Relâche); and the sum of the parts, as others have observed, makes the whole seem very much like a rondo. That is, the opening music reappears in Sections II, V, VII, and X, while the other sections provide various kinds of contrast. Section III has the playful character of a scherzo; Section IV balances this excursion with an episode of lyric repose. And it is intriguing to note that the former moves to the subdominant side of the opening key area (D major in relation to $A$ major), while the latter centers in the dominant. These are completely "normal" keys for rondo episodes-although to a certain degree their normal positions and characters have been reversed, as if in parody of conventional expectations.

If this interpretation is correct, the question arises why Satie would follow such a (neo-)classical model in a film so contemporary in feeling. ${ }^{31} \mathrm{~A}$ partial answer has already been offered in the attempts to explain the recurrences of the opening theme within Sections I and II. They were said to be derived from the logical similarities of the images the music accompanies; and the same logic can be traced through the rest of the score. When the opening music returns at the beginning of Section $\mathrm{V}$ 
it seems to bring us home; but of course "home" in Entr'acte is up in the air-with the bouncing discs, the boxing gloves, the paper boat, and the egg on water. The same music accompanies all but one of these images, and that one (the boat) has special "airborne" music of its own. Thus the structural organization of the score can be intimately linked to one of the film's fundamental patterns of imagery.

These patterns are sustained throughout the remainder of the film, but at the same time Section V marks a major shift in Entr'acte toward a relatively continuous narrative, which grows out of Börlin's assassination. A mock funeral procession ensues (in Sections VI and VII), with the hearse, as mentioned above, led by a camel, and the mourners, following behind, leaping in slow motion. Normal motion eventually resumes, and the procession circles a diminutive model of the Eiffel Tower in the Luna amusement park. Suddenly the hearse comes loose from the camel's reins. It begins to roll away, faster and faster, and a runaway chase accelerates into a dazzling parody of a Mack Sennet comedy that climaxes with a dizzying upside-down ride on a roller coaster (Section VIII). Finally the coffin falls from the hearse and tumbles to rest. The panting mourners (still in pursuit!) catch up, and-out pops Börlin (Section IX). With a magician's wand he makes everyone, himself included, disappear. "Fin," says the screen-only to be exploded by one more joke. Börlin bursts through the canvas sign to tell us that this is not the end (as indeed it is not, since the second act of Relâche is supposed to follow). De Maré enters angrily, remonstrates with his "star," then knocks him down and kicks him in the head. Börlin hurtles backward through the ripped canvas, which heals itself into the final, conclusive "FIN."

Because the second half of the film is more continuous than the first, sectional cadences play a less important role in defining the musical structure; but although the music is more continuous, the sections themselves are highly contrasted, and Satie brings a succession of old and new techniques into play. Section VI, for example, like Section IV, is a slow episode-but this time a Funeral March rather than a waltz. The music begins in the tonic minor (a common key for a contrasting episode in the center of a rondo), and for the first time the composer parodies conventional silent-film scoring in an obvious way, by alluding to Chopin's Funeral March-a familiar piece, often heard in silent theaters. But Satie quotes the music in the wrong 
key and then somewhat disrespectfully imposes his own tune on the warhorse's back (Ex. 8):

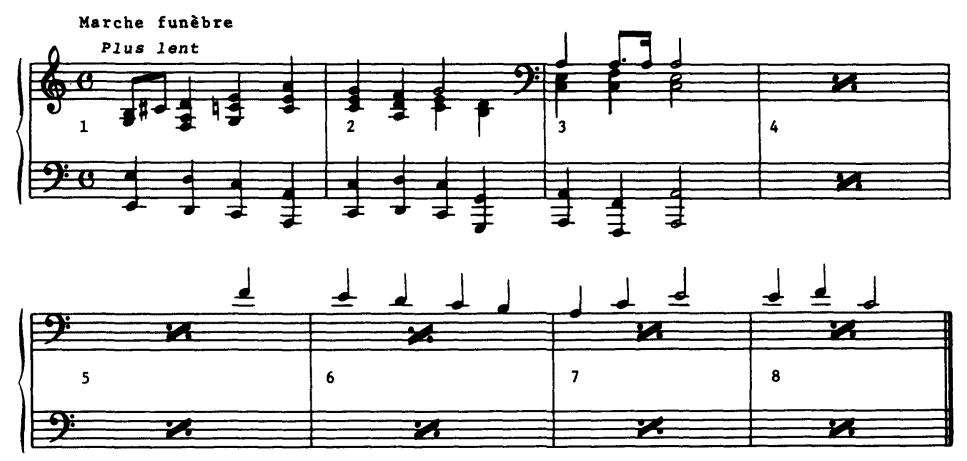

Satie: Entracte, the first unit of Section VI.

Example 8

Other tunes follow, all born by the funereal dotted rhythms which hold this section together. Strangely, the march music gives way, so it seems, to a return of the opening theme, precisely when the mourners actually do begin to "march" (Section VII). In context, however, it is difficult to avoid playing this music at about half its customary tempo, in "slow motion" (even though there are no such tempo markings in the score). The dotted rhythms of the opening theme thus become as funereal as those in Section VI, and once again the return of this music is triggered by objects "up in the air"-this time the mourners themselves.

Several more units accompany the dreamlike procession, all rather weightless in feeling. They are succeeded by perhaps the two most complex units of the second half of the score (Exx. $9 a \& 9 b)$, used by Satie to lead into the chase at the beginning of Section VIII: 
a)
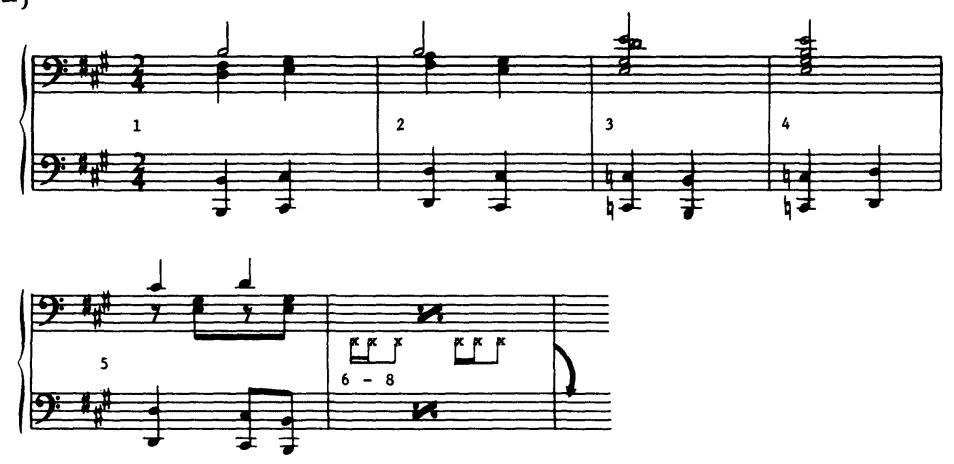

b)

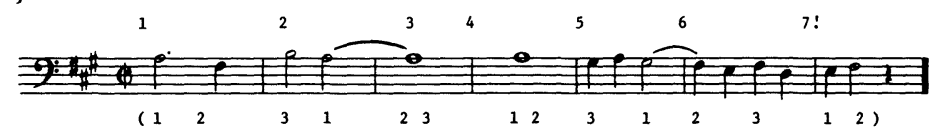

Satie: Entr'acte, the first unit of Section VIII.

Example 9

In the first of these, a meandering series of chords accelerates (through rhythmic diminution) into a counterpoint of lines that move in opposite directions (mm. 5-8). The chords share the aimless quality of the units in Section VII, but their minor harmonies and dark timbres are slightly ominous, as if to create tension while the hearse slips away. The rhythmic acceleration (driven by the snare drum introduced in $\mathrm{m}$. 6) pushes the music forward into an altogether surprising chase theme: a modalsounding, hymn-like line that covers seven (!) duple measures. This theme (as indicated in Ex. 9b) is rhythmically ambiguous enough to be heard in triple meter. ${ }^{32}$ The metrical instability helps the film accelerate into the chase; and at the same time the theme's pomposity also comments ironically on what we see: the male mourners, black-frocked and hatted, stepping faster and faster until they reach a furious fast-motion run. Three times this dignified music is repeated, undercutting the mourners' ever-quickening strides. Moreover, each time its solemnity is increased by an enrichment of instrumentation and harmony. Thus, even though the theme serves as an ironic counterpoint to the action, it does parallel the film's rhythmic 
acceleration, but with a developmental expansion of texture, rather than an increase in tempo. (This kind of audio-visual relationship remains rare even today.)

Once the chase takes off, these sophisticated musical effects recede, to be replaced by a series of eight units as simple as any in the score. All are eight measures long, and all contain onemeasure patterns. The music has retreated to a less assertive style, in deference to Clair's complex visual structures, which are developed most fully in this portion of the film. As the chase builds, however, the music does build with it: both the pitch and dynamic levels rise, and the number of instruments steadily increases. (Compare the first and last of these units, Exx. 10 \& 11):

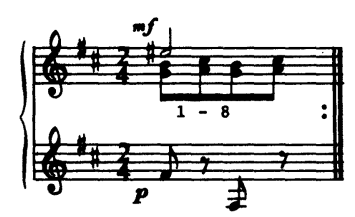

Satie: Entr'acte, the first "chase" unit.

Example 10

This music leads to the climactic roller-coaster ride, an ever more confused blur of several dozen shots, for which Satie cleverly decided to reinvoke the technique of repetition of a single unit ad lib (Ex. 11):

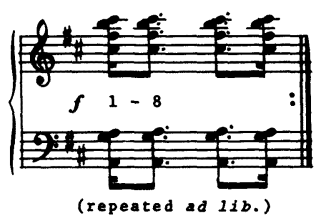

Satie: Entr'acte, the last "chase" unit.

Example 11

As was the case the first time, the pattern being repeated is highly dissonant and suspenseful; but now we are not waiting for an action to transpire (like the shootings of the egg and Börlin) so much as for an end to the action. Film can move no faster 
than it does here, and the repetitive music pulls against it. Melodically it does not budge, and the syncopated rhythms feel like brakes on the runaway hearse. The longer the sequence and the musical repetitions continue, the more the sense of friction builds; and thus the same paradox is in force as before: an obtrusive, seemingly autonomous piece of music increases the film's dramatic effect. Moreover, resolution is denied once more, since the music simply stops when once again Börlin (now in his coffin) falls. ${ }^{33}$

A slower section ensues; like the mourners, the music must pause to catch its breath. Section IX presents a series of slow units in triple time that vaguely recall the music of the ballerina's section, with similar circular patterns that gently move through very small ranges. In this section, however, the patterns do not arch and float; they rise chromatically and weakly, depicting post-chase exhaustion. The first of them also seems to depict the open country where the coffin comes to rest, by introducing a tambourine, Satie's ironic touch of "local color" (Ex. 12):

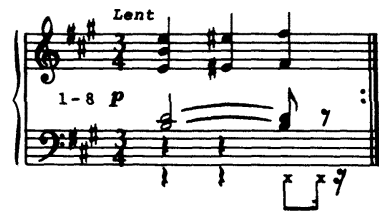

Satie: Entracte, the first unit of Section IX.

Example 12

The irony is that Entr'acte's geography is such that we do not really know where we are. Even if the chase has carried us and the hearse all the way to the Pyrenees, Börlin hops and dances in the field like the ballerina in her studio (one reason, perhaps, for the musical similarities); it is as if he were still on stage (where, in fact, he shortly would be, were Relâche to resume). In a delightful non sequitur he ends the show. One by one he makes his "audience" disappear, accompanied by a very soothing pattern closing on a dominant softened with an added sixth (Ex. 13): 


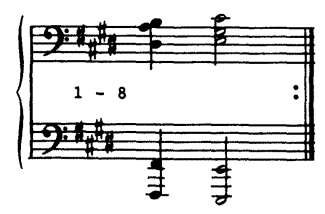

Satie: Entr'acte, the last unit of Section IX.

Example 13

The music fades away, and the film fades from sight, without a trace of energy remaining.

But with one more explosion, Satie pulls the energetic opening theme out of the air. We feel the half-humorous bow to classical symmetry contained in this gesture; we also sense the appropriateness of the return, since the ending of Entr'acte puts the film once again up in the air, when Börlin reappears. The extensions of the theme which follow constitute its first transformations in the score. They pile up thirds into an augmented triad that itself augments the tension of the argument between Börlin and De Maré. When Börlin is finally knocked to the ground (for the third time in the film), the music crashes down from its heights too, with brutal chords matched to the kicks in the dancer's heads (Ex. 14):

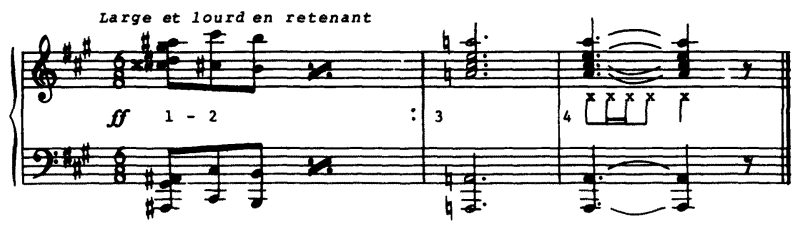

Satie: Entr'acte, the end of Entr'acte.

\section{Example 14}

They cease, and while De Maré tells us not to go away-even the second ending is not truly the end-an A major triad holds the floor, triumphantly sounded by the entire orchestra. This is the score's final irony: the film will not be still, but the opening theme, after bouncing in the air over a period of twenty minutes, has finally come to rest on what is presumed to be stable ground. 
On what ground does this analysis presume to rest? How do we assess Satie's achievement as a composer of film music?

Truly his Entr'acte score is "good" film music-good not for being unobtrusive or subordinate, but because it is so evenly matched to its film on both large and small points, in both style and structure. Entracte is lively, puzzling, and funny. From its opening bursts of light to the closing kicks in the head the film challenges and delights us by hanging in the air, on a screen far above us all; and with this score Satie sought likewise to lift us out of this world into the world of film.

Yet we should not claim for the score, for all its success, the status of "a model of film music." It has too many special subtleties, paradoxes, and ironies to serve as one either for its own time or ours. Nor should we hail it as the "supreme example" of Satie's furniture music. Furniture comes in models, but good film music does not; and while the same piece of furniture, or the same wallpaper design, might work well in many rooms, combined with many kinds of decor, the best film scores show off their virtues only in the light of the films they accompany. Indeed, a piece of furniture may be appreciated even standing alone in a barren room; but the Entr'acte score-heard on its own in a concert hall-might well leave us bored, indifferent, or at best mildly curious. To say that the score has no independent musical life, therefore, is not to equate it with identityless furniture music; rather, the point is to stress how much the music requires the film for its peculiar and very striking characteristics to be understood. We may question, moreover, whether any music is by nature so lacking in presence that its sole function is to remain in the background of some airport, restaurant, supermarket, or theater. Is the concept of furniture music a hollow one? Does its supposed vacuity exist merely in the ear of the beholder, to be filled in by analysis and close attention?

Picabia hailed the Entr'acte score as a masterpiece and pronounced it inseparable from the film (see 1924d: 4; 1927: 19; reprinted in 1978: $162 \&$ 181). We may not be carried so far in our judgment, but analysis encourages us to view the score and the film on equal ground and to present the two together whenever possible. By extension, we should also be encouraged to put the film back into its original position in the middle of Relâche; for there are relationships between ballet and film as vital as those here discerned between film and score. (The set of 
Relâche in Act I is one example. It consists of hundreds of metallic discs, made to reflect and shine like automobile headlights. At the beginning of Entr'acte those discs begin to move.) But these larger patterns of music and movement, design and dance, must be traced elsewhere. The object here has been to demonstrate the unique mutual attachment of Entr'acte the film and Entr'acte the score. Their meanings are shared, their structures enfold.

No study of Entr'acte would be complete, however, without some deflating final irony to undermine the conclusion. To read what the three principal creators had to say about Entracte is to be told that both film and music resist analysis. The film is like a dream, said Clair, with all the incoherence of true dreams. ${ }^{34}$ Any attempt to interpret this film by placing its images into rational contexts of meaning violates the "liberation" and purity that the director claimed for them. And Satie? The salient word he applied to his music was "pornographic"-not a term that encourages scholarly interpretation (see Mayr 1924: 11). ${ }^{35}$ We have already observed, moreover, that according to Picabia an essential element of the film is its lack of respect, its laughter at the pretensions of mankind. But what could be more open to ridicule than the attempt to impose rational order on irrational experience? The more systematic the order-that is, the more consistent the analysis-the more it will beg a fundamental question inscribed by Picabia beneath a caricature of Satie on the frontispiece of the Relâche score: "When will we lose the habit of explaining everything?" 36

An attack on the will to explain things is a fundamental aspect of what Dada was all about; yet the twenties was also a time when even seemingly inexplicable phenomena (including dreams) were believed more and more to contain hidden coherencies of their own, thanks to the efforts of such dissimilar explainers as Freud and Breton. The former gave us Psychoanalysis, the latter Surrealism-a movement officially proclaimed during the same period that saw the creation of Entr'acte. ${ }^{37}$ And in a sense the film and its score stand midway between Dada and Surrealism: they are artworks of non-sense and incoherence, but with great creative energy that implies the existence of hidden patterns waiting to be discovered. The patterns we have found-more complex and harmonious than those of any wallpaper-may inspire the ghosts of Picabia, Clair, and Satie with laughter; but so long as we do not take ourselves too seriously, 
we are justified in praising Satie's score for Entr'acte. It is not illustrative music, but it is an illustrious example of the emerging art of film music. 


\section{APPENDIX THE SOURCES FOR ENTR'ACTE}

\section{The Music.}

To my knowledge there are four distinct versions of the Entr'acte score:

1) the orchestral score for flute, oboe, clarinet, bassoon, two horns, two trumpets, trombone, strings and percussion (Paris: RouartLerolle, 1926);

2) a four-hand piano reduction made by Darius Milhaud (Paris: Rouart-Lerolle, 1926)-plate number R.L. 11573 \& Cie;

3) a two-hand piano reduction (Paris: Salabert, 1972)-plate number E.A.S. 17061;

4. a revised orchestral score (Paris: Salabert, n.d.)-plate number E.A.S. 17.207 .

All of these scores bear the somewhat awkward but accurate full title Cinéma: Entr'acte symphonique de "Relâche." The orchestral scores are available on a rental basis only; those copies I have seen all contain conductors' markings in more than one layer.

While no score was published when Satie was still alive, Milhaud describes Satie going over proofs from Rouart-Lerolle shortly before his death on 1 July 1925. (See Milhaud 1949: 195). Satie's so-called "cue sheets" (described in the text above, and in note 23), may actually have been drafted at this time as a short-hand guide-for himself, possibly, as he proof-read, or for Rouart-Lerolle, or for Milhaud to use in making his reduction-so that the cues would be printed in their proper places. It is thus not safe to assume these pages are precompositional jottings; but whatever their point of origin, they remain the composer's only "sketches" known to be directly related to the score.

One more musical source deserves mention: the recording on Candide Records, No. 31018, performed by the Ensemble Reihe under the direction of Friedrich Cerha. This recording makes one vividly aware of the problems which arise when performing Entracte. For example: on the recording, nearly every musical unit is repeated at least once, and often there are modifications of tempo. Such adjustments are unavoidable, as I have discovered, when using the score to accompany the film; but on the Cerha recording they are taken to an extreme, without explanation. The liner notes do not make clear the circumstances behind the recording. If it originated in an actual synchronized performance of film and music, however, the tempos and repetitions indicate that the film was run at or near the speed of sixteen frames per secondand one wonders if such a slow speed is appropriate. 


\section{The Film.}

I have worked with prints of Entr'acte from the Museum of Modern Art in New York, the MIT Film Study Center, and the Harvard Film Archive (to whose Curator, Vlada Petric, I am most grateful). All of these prints differ in details, as do the analytical scripts published in Italian and French (described in note 7). Should any of these versions be called "definitive?" Or should that term be given to the synchronizedsound version made in 1968, with music conducted by Henri Sauget? As Sauget was a friend of Satie during the latter's final years, this version may well lay claim to authority; moreover, it was apparently authorized by Clair as well. But without having been able to see the film, I cannot help wondering whether a projection speed of twentyfour frames per second is the best one for this film-or, more generally, whether a mechanical reproduction of the Entr'acte score is as suitable or exciting as a live performance.

Given these uncertainties, I have tried to steer my analysis clear of textual problems (or to indicate such problems clearly, as in notes 29 and 33). There is much that could be gained from having a critical edition of the score, and also a scholarly examination of the film's own history from 1924 to the present. But the problems are perhaps less menacing than stimulating. Silent film accompaniments were, of necessity, inherently flexible; and some spontaneity should not be denied their interpreters-especially when dealing with a work of Picabia and Satie. 


\section{NOTES}

1. Other ballets premiered by the company include Les Mariés de la Tour Eiffel (1921), Skating Rink (1922), and La Création du monde (1923)-the latter two being revived on the same program as Relâche. For histories of the company, see Les Ballets Suédois (1931), and Beaumont (1938) (on Jean Börlin, pp. 667-84).

2. Pierre de Massot wrote this letter to Picabia on 22 January 1924 inviting his collaboration on the project on Satie's behalf; it is partially cited in Sanouillet (1966: 168). The letter can be consulted at the Bibliothèque Littéraire Jacques Doucet (Paris), in the Dossiers Picabia, Vol. 10, p. 331.

3. Satie's letter to Milhaud, 27 September 1924, is cited in Bélicha (1978: 49).

4. To cite one example, Picabia's final issue of 391 (October 1924) announced the ballet with the exhortation to "Bring dark glasses and something to plug your ears .... Ex-Dadaists are invited to come riot and especially to cry: 'Down with Satie! Down with Picabia! Long live the Nouvelle revue française!' See Sanouillet (1960: 130). At a performance of Satie's previous ballet, Mercure, in June 1924, Aragon had provoked a riot by leaping on stage and crying: "Long live Picasso! Down with Satie!" Picabia responded with the polemic "Erik Satie" (1924b); reprinted in Picabia (1978: 145-47). Here Picabia proudly announced his collaboration with Satie on Relâche, concluding: "I cry: 'Long live Erik Satie!' "

5. Apparently the ballet was postponed because Börlin was ill. Relatively comprehensive accounts of Relâche, including descriptions of both its aborted and actual premieres can be found in Wehmeyer (1974: 258-92); Harding (1975: 222-33); and Camfield (1979: 208-14).

6. According to Holland (1980) there have been four revivals, all since 1970. The most recent (and the first in the United States) was given by the Joffrey Ballet in New York in November 1980, with choreography by Moses Pendleton.

7. There are three published Entr'acte scripts: in Italian (Viazzi [1945]); in French (L'Avant-Scène du cinéma, No. 86 [November 1968], 11-16); and in English (Clair [1970]). All shot references below are to the English version.

8. I have found the following studies especially helpful: Mitry (1960); Dale (1978); and Sandro (1979).

9. This essay was reprinted in the program for Relâche, i.e., the special issue of La Danse devoted to the Ballets Suédois (NovemberDecember 1924), "Page René Clair," and can be found in Picabia (1978: 167). 
10. Apollinaire termed the cinema one of the most important "new means of artistic expression" in a 1917 lecture (published the following year) on "The New Spirit and the Poets"; reprinted in Roger Shattuck's English translation in Apollinaire (1950: 237); by an interesting coincidence it was also Apollinaire who had termed Satie's ballet Parade "the starting point ... of that New Spirit," in a statement for the ballet's program (see Harding [1975: 158-59]).

11. See also Picabia (1924a); reprinted in Picabia (1978: 167). On the Parisian avant-garde's first approaches to cinema, see Brunius (1949). As the editor of Films in 1923 and 1924, Clair had become one of the experimental cinema's leading spokesmen; much of his writing can be found in Clair (1972).

12. All the musical examples are based primarily on the twopiano reduction described in the Appendix. In a few examples percussion parts have been added, in order to convey the complete rhythmic structure of a unit.

13. The importance of Entr'acte as an example of furniture music has been affirmed in all of the major Satie studies. Compare Myers (1968: 60-61); Templier (1969: 45-46; 110); Wehmeyer (1974: 227-29; 279-89); and Harding (1975: 196-98). Also important in promoting this point of view have been Mellers (1942: 223-26); Shattuck (1968: 170-72); and Gallez (1976).

14. From an undated (1918?) letter to Jean Cocteau; see the special issue of Les Empreintes, No. 7 (1950), p. 98, for a facsimile of the entire letter.

15. References to musique d'ameublement are widely scattered among Satie's letters, notebooks, and manuscript jottings. They have not yet been collected. In addition to the sources mentioned above (note 13), see, especially, Volta (1977: 187-90), and also her collection of documents with commentary (1979: 73). The latter contains one of the two facsimiles of furniture music sketches by Satie that I know of; the second one can be found in Rey (1974: 124).

16. Entracte is scored for flute, oboe, clarinet in A, and bassoon; two horns in F, two trumpets, and one trombone; strings; and a percussive battery that includes snare drum, cymbals, wood block, bass drum, gong, triangle, and tambourine. Only in the last twelve measures do all members of the orchestra play together.

17. Many prints of Entracte now in circulation begin with a "Prologue," originally projected at the beginning of Relâche; it features Satie and Picabia, descending into the frame in slow motion, loading a cannon, and gleefully firing it in our faces (see Clair [1970: 115-16]).

18. Based on the shot-by-shot analysis in Clair (1970: 121). It should be noted, however, that in the Clair script the Prologue and titles are included. Hence Clair's numbering differs from mine. As far as Satie's score is concerned, the true beginning of Entr'acte is my shot 1. 
19. From one of Picabia's pre-Relâche promotional essays (1924d); cited by Camfield (1979: 212), and reprinted in full in Picabia (1978: 159-60). Camfield terms "Instantanéisme" a "one-man 'movement'"Picabia's "antidote to Surrealism" (1979: 208). Relâche itself was advertised as a "ballet instantanéiste."

20. Compare shots 28, 54, and 56 of the Entr'acte screenplay.

21. "In Entr'acte," writes Clair, "the image, 'turned away from its obligatory meaning,' is born into 'a concrete existence." (Clair's quotations come from an essay by André Breton, "Les Mots sans rides," first published in 1922 and reprinted in Breton [1924: 167-71].) The director gives Picabia the credit for "liberating" both words and images: "My task was limited to the technical realization of Picabia's ideas." But in his own parallel essay, Picabia gives Clair the lion's share of credit: "I gave René Clair a trifling scenario of nothing at all; out of it he made a masterpiece" (1924a).

22. The simile is from Mitry (1960: 20).

23. Gallez terms these cue sheets "Satie's working notes" and interprets their notation (see 1976: 38-40); his transcription is somewhat misleading, however, when compared with the cue sheets themselves. There are four of these pages (" $A$ " and " $B$ " back to back on one sheet, "C" and " $D$ " on another), divided between the Houghton Library, Harvard University, and the Bibliothèque Nationale, Paris. Facsimiles of "A" can be found in Templier (1969: Plate 83); Rey (1974: 148); and Volta (1979: 87). See also the Appendix.

24. On the first of these cue sheets ("A"), the layout and corrections show that Satie at one point intended these two sections to be linked under a single heading.

25. The sequence begins with shot 64 .

26. See shots 93-109.

27. Gallez notes the transitional rhythmic effect (see 1976: 47). The link becomes more obvious when the unit is performed (as in the Candide recording described in the Appendix) with a ritardando.

28. Shot 121.

29. These instructions appear only in the 1926 edition of the orchestral score. Gallez (1976: 41) attributes them to Roger Désormières, conductor of the premiere. In the Candide recording this unit is repeated five times, with a very broad ritardando that anticipates the tempo of the following section.

30. As early as 1892 Satie had composed a fragment called "Vexations" to be played 840 times. See Wehmeyer (1974: 46; 229).

31. Gallez terms the music "an unorthodox rondo, but not a classical one" (1976: 43); Wehmeyer asserts that the score's rondo form finds no analogous repetitive structure in the film (see 1974: 288).

32. The ambiguity is noted by Gallez (1976: 47), but he offers no explanation for it. 
33. Instructions in the 1926 orchestral score call for the unit to be played ten times; but in the recorded performance on Candide it is played nine times, accelerando. It should also be noted that according to Gallez (1976: 41), an instruction for ad lib repetition appears once more, at the end of Section IX; but I have not seen this in the copies of the score made available to me.

34. According to Sanouillet (1966: 169), citing the Dossiers Picabia, Vol. 10, p. 253.

35. Six days later Satie sent a letter to Milhaud in which he enclosed a sketch from Relâche-"Ballet obcène" [sic] (see Wehmeyer [1974: 284-85]). But in the ballet program, Satie was more modest: "I would not want [my music] to make a lobster blush, nor an egg." See the "Page Erik Satie" of La Danse (note 9), given in facsimile in Wehmeyer (1974: 276), and in Camfield (1979: Plate 253).

36. The score of Relâche was published in piano reduction (Paris: Rouart-Lerolle, 1926), plate number R. L. 11577 \& Cie; the frontispiece is no longer included with the score, but facsimiles can be found in Myers (1968: 106) and in Volta (1979: 82).

37. In 1924 André Breton published his first Manifeste du Surréalisme; Picabia responded antagonistically with his own manifesto: his last issue of 391 (October 1924) was called the Journal de l'Instantanéisme, which has been taken as his attempt to resuscitate Dada (just in time for the presentation of Relâche). See Sanouillet (1966: 166). 


\section{REFERENCES}

APOLLINAIRE, G.

1950: Selected Writings of Guillaume Apollinaire. Translated by Roger Shattuck. London: Harvill.

Les Ballets Suédois dans l'art contemporain. Paris: Trianon, 1931.

BEAUMONT, C. W.

1938: Complete Book of Ballets: A Guide to the Principal Ballets of the Nineteenth and Twentieth Centuries. New York: Grosset \& Dunlap.

BÉLICHA, R.

1978: "Chronologie Satiste ou Photocopies d'un original," La Revue musicale, No. 312, 7-63.

BRETON, A.

1924: Les Pas perdus. Paris: Gallimard.

BRUNIUS, J.

1949: "Experimental Film in France," in Manvell, ed., Experiment in Film. London: Grey Walls Press, 60-112.

CAMFIELD, W. A.

1979: Francis Picabia: His Art, Life and Times. Princeton: Princeton University Press.

CLAIR, R.

1924: "Avant l'Entr'acte," Films (Supplement to Le Théâtre et Comoedia illustré, No. 28 (November), [p. 3].

1970: $\grave{A}$ Nous La Liberté and Entr'acte. Translated by Richard Jacques and Nicola Hayden. New York: Simon \& Schuster.

1972: Cinema Yesterday and Today. Translated by Stanley Appelbaum and edited by R. C. Dale. New York: Dover.

DALE, R. C.

1978: "René Clair's Entr'acte, or Motion Victorious," Wide Angle, II/2, 38-43.

GALLEZ, D.

1976: "Satie's Entr'acte: A Model of Film Music," Cinema Journal, XVI/1, 36-50.

HARDING, J.

1975: Erik Satie. London: Secker \& Warburg.

HOLLAND, P.

1980: "Relâche Revisited," Ballet News, II/5, 26-30.

MAYR, W.

1924: "Entretien avec Erik Satie," Le Journal littéraire, No. 24 (4 October), p. 11.

MELLERS, W.

1942: "Erik Satie and the 'Problem' of Contemporary Music," Music and Letters, XXIII/3, 210-27. 
MILHAUD, D.

1949: Notes sans musique. Paris: Julliard.

MITRY, J.

1960: René Clair. Paris: Éditions Universitaires.

MYERS, R. H.

1968: Erik Satie. New York: Dover.

PICABIA, F.

1924a: "À propos d'Entracte," Films (Supplement to Le Théâtre et Comoedia illustré, No. 28 (November), [p. 3].

1924b: "Erik Satie," Paris-Journal, 27 June, p. 1.

1924c: "Instantanéisme," Comoedia, 21 November, p. 4.

1924d: "Pourquoi j'ai écrit Relâche," Le Siècle, 27 November, p. 4. 1927: "Entr'acte: un peu de Picabia au Star," Le Journal des hivernants, January, p. 19.

1978: Écrits: 1921-1953 et posthumes. Edited by Olivier Revault d'Allonnes and Dominique Bouissou. Paris: Éditions Pierre Belfond.

REY, A.

1974: Erik Satie. Paris: Seuil.

SANDRO, P.

1979: "Parodic Narrative in Entr'acte," Film Criticism, IV/1, 44-55. SANOUILLET, M.

1960: 391, Vol. I. Paris: Le Terrain Vague.

1966: Francis Picabia et "391", Vol. II. Paris: Eric Losfeld.

SHATTUCK, R.

1968: The Banquet Years: The Origins of the Avant-Garde in France, 1885 to World War I, rev. ed. New York: Vintage Books.

TEMPLIER, P. D.

1969: Erik Satie. Translated by Elena L. French and Davis S. French. Cambridge, Mass.: The MIT Press.

VIAZZI, G., ed.

1945: Sceneggiature (Biblioteca cinematografia 2nda serie). Milan: Polignono Società.

VOLTA, O.

1977: Erik Satie: Écrits. Edited and annotated by Ornella Volta. Paris: Éditions Champ Libre.

1979: L'Ymagier d'Erik Satie. Paris: Éditions Francis Van de Velde. WEHMEYER, G.

1974: Erik Satie. Regensburg: Gustav Bosse. 